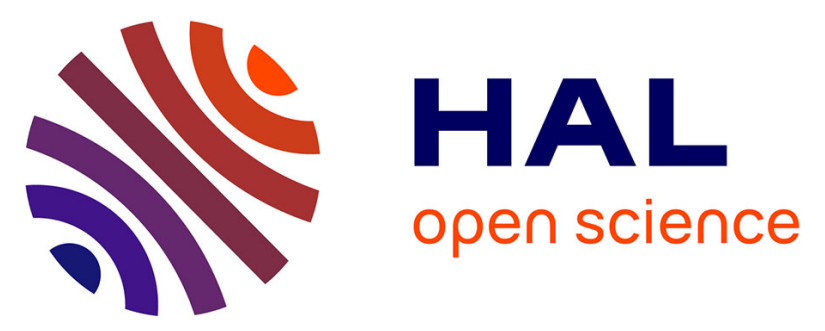

\title{
VEGF165b, a splice variant of VEGF-A, promotes lung tumor progression and escape from anti-angiogenic therapies through a $\beta 1$ integrin/VEGFR autocrine loop
}

Asma Boudria, Cherine Abou Faycal, Tao Jia, Stéphanie Gout, Michelle Keramidas, Chloé Didier, Nicolas Lemaître, Sandra Manet, Jean-Luc Coll, Anne-Claire Toffart, et al.

\section{To cite this version:}

Asma Boudria, Cherine Abou Faycal, Tao Jia, Stéphanie Gout, Michelle Keramidas, et al.. VEGF165b, a splice variant of VEGF-A, promotes lung tumor progression and escape from antiangiogenic therapies through a $\beta 1$ integrin/VEGFR autocrine loop. Oncogene, 2018, 10.1038/s41388018-0486-7 . inserm-02337530

\section{HAL Id: inserm-02337530 https://www.hal.inserm.fr/inserm-02337530}

Submitted on 29 Oct 2019

HAL is a multi-disciplinary open access archive for the deposit and dissemination of scientific research documents, whether they are published or not. The documents may come from teaching and research institutions in France or abroad, or from public or private research centers.
L'archive ouverte pluridisciplinaire HAL, est destinée au dépôt et à la diffusion de documents scientifiques de niveau recherche, publiés ou non, émanant des établissements d'enseignement et de recherche français ou étrangers, des laboratoires publics ou privés. 


\section{VEGF $_{165} \mathrm{~b}$, a splice variant of VEGF-A, promotes lung tumor progression}

and escape from anti-angiogenic therapies through a $\beta 1$ integrin/VEGFR

\section{autocrine loop}

Asma Boudria ${ }^{1,2}$, Cherine Abou Faycal ${ }^{1,2^{*}}$, Tao $\mathrm{Jia}^{1,2^{*}}$, Stephanie Gout ${ }^{1,2}$, Michelle Keramidas $^{2,3}$, Chloé Didier ${ }^{2,3}$, Nicolas Lemaître ${ }^{2,5}$, Sandra Manet ${ }^{2,4}$, Jean-Luc Coll ${ }^{2,3}$, AnneClaire Toffart ${ }^{2,5}$, Denis Moro-Sibilot ${ }^{2,5}$, Corinne Albiges-Rizo ${ }^{2,4}$, Véronique Josserand ${ }^{2,3}$, Eva Faurobert $^{2,4}$, Christian Brambilla ${ }^{2,5}$, Elisabeth Brambilla ${ }^{2,5}$, Sylvie Gazzeri ${ }^{1,2}$ and Beatrice Eymin $^{1,2 \S}$

${ }^{1}$ INSERM U1209, UMR CNRS 5309, Team RNA splicing, Cell Signaling and Response to Therapies, Grenoble, 38042, France

${ }^{2}$ Université Grenoble Alpes, Institut Albert Bonniot, Grenoble, 38041, France.

${ }^{3}$ INSERM,U1209, UMR CNRS 5309, Team Cancer Targets and Experimental Therapeutics, Grenoble, 38042, France.

${ }^{4}$ INSERM U1209, UMR CNRS 5309, Team Cell Adhesion Dynamics and Differentiation, Grenoble, 38042, France

${ }^{5}$ INSERM U1209, UMR CNRS 5309, Team Tumor Molecular Pathology and Biomarkers, Grenoble, 38042, France

Running title: $\mathrm{VEGF}_{165} \mathrm{~b}$ and tumor progression

* Both authors contributed equally

§ Corresponding author:

Dr. Beatrice Eymin INSERM U1209, CNRS UMR5309 Institute For Advanced Biosciences, BP170 38042 Grenoble Cedex 09, FRANCE

Tel: +33476549476/ Fax: +33476549413

email: Beatrice.Eymin@ujf-grenoble.fr

To whom requests for reprints should be addressed 


\section{Abstract}

Vascular Endothelial Growth Factor-A (VEGF-A) is highly subjected to alternative premRNA splicing that generates several splice variants. The $\mathrm{VEGF}_{\mathrm{xxx}}$ and $\mathrm{VEGF}_{\mathrm{xxx}} \mathrm{b}$ families encode splice variants of VEGF-A that differ only at the level of six amino acids in their Cterminal part. The expression level of $\mathrm{VEGF}_{\mathrm{xxx}}$ splice variants and their function as proangiogenic factors during tumor neo-angiogenesis have been well-described. The role of VEGF $_{x x x} b$ isoforms is less well known, but they have been shown to inhibit VEGF $_{x x x}$ mediated angiogenesis, while being partial or weak activators of VEGFR receptors in endothelial cells. On the opposite, their role on tumor cells expressing VEGFRs at their surface remains largely unknown. In this study, we find elevated levels of $V_{E G F}$ bs , the main VEGF $_{\mathrm{xxx}} \mathrm{b}$ isoform, in $36 \%$ of Non Small Cell Lung Carcinoma (NSCLC), mainly lung adenocarcinoma $(46 \%)$, and show that a high $\mathrm{VEGF}_{165} \mathrm{~b} / \mathrm{VEGF}_{165}$ ratio correlates with the presence of lymph node metastases. At the molecular level, we demonstrate that $\mathrm{VEGF}_{165} \mathrm{~b}$ stimulates proliferation and invasiveness of two lung tumor cell lines through a VEGFR/ $\beta 1$ integrin loop. We further provide evidence that the isoform specific knock-down of $\mathrm{VEGF}_{165} \mathrm{~b}$ reduces tumor growth, demonstrating a tumor promoting autocrine role for $\mathrm{VEGF}_{165} \mathrm{~b}$ in lung cancer cells. Importantly, we show that bevacizumab, an anti-angiogenic compound used for the treatment of lung adenocarcinoma patients, increases the expression of $V_{E G F}{ }_{165} \mathrm{~b}$ and activates the invasive VEGFR/ $\beta 1$ integrin loop. Overall, these data highlight an unexpected role of the $\mathrm{VEGF}_{165} \mathrm{~b}$ splice variant in the progression of lung tumors and their response to anti-angiogenic therapies.

Keywords: anti-angiogenic therapies; lung tumor; pre-mRNA alternative splicing; $V_{E G F}{ }_{165} \mathrm{~b}$. 


\section{Introduction}

Angiogenesis is a complex process that contributes to various pathologies including cancer (1, 2). Vascular Endothelial Growth Factor-A (VEGF-A) is secreted by tumor cells and plays a crucial role in different aspects of tumor-induced angiogenesis. Binding of VEGF-A to its cognate tyrosine kinase receptors VEGFR-1 (Flt-1) or VEGFR-2 (Flk-1/KDR) and their coreceptors neuropilin-1 and neuropilin-2, promotes the activation of downstream signaling pathways that control proliferation, survival and migration of endothelial cells during neoangiogenesis $(3,4)$. It has become apparent that the function of VEGF-A is not restricted to angiogenesis and vascular permeability (5). Besides acting on endothelial cells through paracrine signaling, VEGF-A also impacts tumor cells themselves, especially those that express VEGF receptors and neuropilins, including lung tumors (6). Such VEGF-A autocrine signaling is essential for tumor initiation, survival, proliferation or invasion as it promotes dedifferentiation, and epithelial to mesenchymal transition, but also because it regulates the selfrenewal of cancer stem cells (7-10). Recent studies have revealed VEGF-A biology to be even more complex. As an example, VEGF-A prevents tumor cell invasion and mesenchymal transition in glioblastoma through activation of a MET/VEGFR2 signaling pathway (11). In early squamous lung carcinoma patients, combination of high levels of VEGF-A, VEGFR1 and VEGFR2 is associated with a better rather than a worse outcome (12).

VEGF-A is expressed as multiple isoforms that result from pre-mRNA alternative splicing (13). Two families of isoforms, $\mathrm{VEGF}_{\mathrm{xxx}}$ and $\mathrm{VEGF}_{\mathrm{xxx}} \mathrm{b}$ are generated through the use of alternative 3' splice acceptor sites in exon $8(14,15)$. This leads to the synthesis of proteins with the same length as the $\mathrm{VEGF}_{\mathrm{xx}}$ isoforms, but with a distinct C-terminal domain. Owing to the absence of basic carboxy-terminal amino acids essential for neuropilin-1 binding, 
$\mathrm{VEGF}_{165} \mathrm{~b}$, the main $\mathrm{VEGF}_{\mathrm{xxx}} \mathrm{b}$ isoform, is able itself to stimulate some VEGFR signaling (1618). However, it cannot trigger a strong and sustained activation of VEGFR2, and it is also able to prevent $\mathrm{VEGF}_{165}$ signaling that results in angiogenesis in endothelial cells (14, 19-22). Therefore, $\mathrm{VEGF}_{\mathrm{xxx}} \mathrm{b}$ isoforms inhibit the phosphorylation and angiogenic capacity of VEGF $_{x x x}$ isoforms. In various tumors such as melanoma (20), a decrease of VEGF $_{165} b$ correlates with a poor prognosis. On the opposite, high levels of $\mathrm{VEGF}_{\mathrm{xxx}} \mathrm{b}$ proteins have been observed in some tumors, such as infiltrating ductal breast carcinoma (17). Up to now, it is not known whether $\mathrm{VEGF}_{165} \mathrm{~b}$ impacts tumor cells themselves that express VEGFR receptors.

Owing to the crucial role of neo-angiogenesis in tumor development, several anti-angiogenic therapies have been developed that inhibit either VEGF-A binding or VEGFR tyrosine kinase activity. However, these therapies modestly improve overall survival. Recent studies have highlighted $V E G F-A$ pre-mRNA splicing as a potential reservoir for predictive biomarkers to anti-angiogenic therapies. As an example, high plasma levels of the shortest and most diffusible VEGF-A isoform $\left(\mathrm{VEGF}_{121}\right)$ were correlated with improved Progression Free Survival (PFS) and/or Overall Survival (OS) in breast, gastric or pancreatic cancer patients treated with the humanized monoclonal anti-VEGF-A antibody, bevacizumab $(23,24)$. In addition, metastatic colorectal cancer patients with a low $\mathrm{VEGF}_{165} \mathrm{~b}: \mathrm{VEGF}_{\text {total }}$ tumor ratio had a better outcome when treated with the combination of the FOLFOX4 chemotherapeutic protocol with bevacizumab compared to FOLFOX4 alone (25). Therefore, deciphering the expression pattern and specific functions of $\mathrm{VEGF}_{\mathrm{xxx}}$ and $\mathrm{VEGF}_{\mathrm{xxx}} \mathrm{b}$ splice isoforms in tumors might be critical when considering the response to these therapies. 


\section{Results}

\section{Human lung adenocarcinomas express high levels of VEGF ${ }_{165}$ b}

In order to analyze the status of $\mathrm{VEGF}_{165} \mathrm{~b}$ and of its pro-angiogenic counterpart $\mathrm{VEGF}_{165}$ in lung tumors, we first performed immunohistochemistry in a series of normal lung parenchyma tissues and 76 NSCLCs, including 41 adenocarcinomas (ADC) and 35 squamous cell lung carcinomas (SCC) using specific anti-VEGF ${ }_{165}$ and anti-VEGF $\mathrm{VES}_{165} \mathrm{~b}$ antibodies we generated in the laboratory (see Materials and Methods and Supplementary Figure 1a). In normal lung, a moderate diffuse cytoplasmic staining of both $\mathrm{VEGF}_{165}$ and $\mathrm{VEGF}_{165} \mathrm{~b}$ isoforms was observed in bronchial basal cells and hyperplastic type II pneumonocytes (Supplementary Figures $1 \mathrm{~b}$ and 2). As compared to normal lung tissues, NSCLCs had a more heterogeneous pattern of $\mathrm{VEGF}_{165} \mathrm{~b}$ staining with $36 \%$ (27/76) of patients expressing high intra-tumoral $\mathrm{VEGF}_{165} \mathrm{~b}$ protein levels (Supplementary Table 1, Figures 1a, Figure 1b and Supplementary Figure 2). Higher intra-tumoral (Figure 1c) or circulating (Figure 1d) $\mathrm{VEGF}_{165} \mathrm{~b}$ levels were specifically observed in lung adenocarcinoma patients, as compared to squamous lung carcinoma or healthy control subjects respectively. In addition, elevated levels of $\mathrm{VEGF}_{165} \mathrm{~b}$ were found in various cellular models derived from lung ADC or SCC compared to immortalized human bronchial epithelial HBEK-3KT cells (Supplementary Figure 1c). Compared to SCC cell lines, most ADC cell lines expressed higher levels of intra-cellular (Supplementary Figure 1c) or circulating (Supplementary Figure 1d) VEGF $_{165}$ b protein level. Moreover, we observed a differential pattern of expression between $\mathrm{VEGF}_{165} \mathrm{~b}$ and $\mathrm{VEGF}_{165}$ in NSCLCs (Figures 1a and 1b, p<0.001; Supplementary Table 1), indicating that both isoforms are not expressed in the same way. Importantly, we noticed that a high $\mathrm{VEGF}_{165} \mathrm{~b}: \mathrm{VEGF}_{165}$ 
ratio correlates with lymph node metastases in NSCLC (Figure 1e). Collectively, these results suggested that high levels of $\mathrm{VEGF}_{165} \mathrm{~b}$ are associated with NSCLC aggressivity.

\section{VEGF $_{165}$ b promotes cell proliferation and lung adenocarcinoma growth}

To deepen the functions of $\mathrm{VEGF}_{165} \mathrm{~b}$ in Non Small Cell Lung Carcinoma, we generated stable VEGF $_{165}$ b-overexpressing clones in two cellular models derived from lung adenocarcinoma, namely $\mathrm{H} 358$ and $\mathrm{H} 1299$. These clones secreted high level of $\mathrm{VEGF}_{165} \mathrm{~b}$ (Supplementary Figure 3a) and proliferated faster than their control counterparts (Figure 2a). Increased cell proliferation was also observed when conditioned medium derived from these clones was applied native cells (Figure 2b), or when cells were treated with recombinant human VEGF $_{165}$ b ligand $\left(\right.$ rhVEGF $_{165}$ b) (Figure $\left.2 c\right)$. On the other hand, transfecting cells with a siRNA specifically targeting the $V E G F_{165} b$ isoform diminished cell proliferation compared to control mismatch transfected cells (Figure 2d). Taken together, these data provided the first evidence that $\mathrm{VEGF}_{165} \mathrm{~b}$ stimulates the proliferation of lung tumor cells.

To validate the results in vivo, we designed sub-cutaneous xenograft experiments in nude mice using H1299 cells stably overexpressing VEGF $_{165}$ b or H358 cells stably expressing the splicing factor SRSF6. Hence, SRSF6 was previously reported to physiologically induce VEGF $_{165} \mathrm{~b}$ expression in primary epithelial cells (26). We confirmed increased expression of VEGF $_{165} \mathrm{~b}$ in H358-derived SRSF6 overexpressing cells compared to H358 control cells despite a reduction in overall VEGF-A level (Supplementary Figure 4a). In addition, HUVEC cells cultured with conditioned medium of the SRSF6 clones were unable to form tubes in matrigel, which was consistent with the anti-angiogenic properties of secreted $\mathrm{VEGF}_{165} \mathrm{~b}$ 
(Supplementary Figure 4b). Importantly, we observed that both H1299-VEGF ${ }_{165}$ b and H358SRSF6 xenografts grow faster than control tumors (Supplementary Figures $3 b$ and 4c), reach higher tumor weights (Supplementary Figure 4d, left panel) and enhanced tumor growth was correlated with increased KI67 staining (Supplementary Figures 3c and 4d right panel) compared to control xenografts. Of note, microvascular density (as revealed by CD31 or a-SMA stainings of neo-vessels) did not significantly vary in H358-SRSF6 xenografts compared to control $\mathrm{H} 358$ tumors which rules out the possibility that $\mathrm{VEGF}_{165} \mathrm{~b}$ promotes growth by modulating tumor neo-angiogenesis in that case (data not shown).

To eliminate unspecific effects related to $\mathrm{VEGF}_{165} \mathrm{~b}$ overexpression, we designed a reverse in vivo experiment in which $\mathrm{H} 358$ cells were sub-cutaneously injected into nude mice, allowed to form tumors. Mice were then sub-divided in 2 groups that received either PBS + mismatch siRNA [mismatch] or $\mathrm{PBS}+V E G F_{165} b$ siRNA [VEGF ${ }_{165} \mathrm{~b}$ ]. Inhibition of $\mathrm{VEGF}_{165} \mathrm{~b}$ expression was detected by immunohistochemistry, while VEGF $_{165}$ expression was not affected by $V E G F_{165} b$ siRNA (Figure 2e). In agreement with a role of $V_{E G F}{ }_{165}$ b in lung tumor growth, tumors deprived of $\mathrm{VEGF}_{165} \mathrm{~b}$ were smaller than control mismatch ones (Figure 2f). Level of hypoxia analyzed by CAIX or HIF1-alpha immunostaining (Supplementary Figure 5), or tumor neo-angiogenesis assessed by CD31 or $\alpha$-SMA endothelial staining (data not shown) was not different between control tumors and tumors deprived of $\mathrm{VEGF}_{165} \mathrm{~b}$. These results strongly suggested that tumor growth inhibition is not associated with decreased neoangiogenesis. Consistently, the knock-down of $\mathrm{VEGF}_{165} \mathrm{~b}$ in $\mathrm{H} 358$-derived xenografts significantly decreased KI67 staining compared to control xenografts (Figure 2g). As a whole, these data demonstrated that $\mathrm{VEGF}_{165} \mathrm{~b}$ stimulates lung tumor proliferation and strongly suggested that autocrine rather than paracrine mechanisms are involved. 


\section{VEGF $_{165}$ b activates a VEGFR-dependent autocrine loop to promote tumor cell proliferation}

We previously showed that lung adenocarcinoma express VEGFR1 and VEGFR2, neuropilin1 and neuropilin-2 receptors (6). Therefore, we tested the impact of $V_{E G F} b$ on VEGFR signalling in our lung tumor cells. We detected a persistent accumulation of activated PVEGFR1(Tyr1213), P-VEGFR2(Tyr1054/1059) and P-VEGFR2(Tyr1214) proteins in H358 and $\mathrm{H} 1299$ cells treated for 72 hours with rhVEGF $_{165}$ b (Figures $3 \mathrm{a}$ and $3 \mathrm{~b}$ ). Same results were found in $\mathrm{H} 358$ and $\mathrm{H} 1299$ clones overexpressing $\mathrm{VEGF}_{165} \mathrm{~b}$ (Figures 3c and 3d). Of note, the activation of VEGFR1/VEGFR2 receptors was detectable at 24 hours of $\operatorname{rhVEGF}_{165} \mathrm{~b}$ treatment, but was not clearly observed at earlier time points (Supplementary Figure 6). The activation of VEGFR1 and VEGFR2 was associated with the downstream accumulation of PERK1/2 (Figures 3a-d), and the inhibition of ERK signaling by the use of U0126, a MEK1 pharmacological inhibitor, slowed-down cell proliferation of $\mathrm{H} 358-\mathrm{VEGF}_{165} \mathrm{~b}$ clones (Figure 3e). Same results were obtained in $\mathrm{H} 1299-\mathrm{VEGF}_{165} \mathrm{~b}$ clones (data not shown). Taken together, these results demonstrated that $\mathrm{VEGF}_{165} \mathrm{~b}$ triggers a sustained activation of VEGFR receptors that correlates with ERK1/2 activation and cell proliferation. Importantly, the knock-down of VEGF $_{165} \mathrm{~b}$ strongly decreased P-VEGFR1(Tyr1213) immunostaining in H358-derived xenografts (Figure 3f), whereas overexpression of VEGF $_{165}$ b in H1299-derived xenografts (Supplementary Figures 3c and 3d) or in SRSF6-expressing H358 xenografts (Supplementary Figure 4e) increased P-VEGFR1(Tyr1213) and P-VEGFR2(Tyr1214) protein levels. These data indicated that $\mathrm{VEGF}_{165} \mathrm{~b}$ may stimulate tumor growth in vivo through activation of VEGFR1 and VEGFR2. Of note, we were not able to assess the phosphorylation status of VEGFR2 in xenografts as the antibody did not give a specific immunostaining pattern. Furthermore, we observed that VEGFRI and/or VEGFR2 mRNA levels increase in cells treated with $\operatorname{rhVEGF}_{165} \mathrm{~b}$ (Figure $3 \mathrm{~g}$ ) and in clones overexpressing $\mathrm{VEGF}_{165} \mathrm{~b}$ (Figure $3 \mathrm{~h}$ ). 
These data indicated that $\mathrm{VEGF}_{165} \mathrm{~b}$ also positively regulates total VEGFR expression. Consistently, VEGFR1 immunostaining decreased in H358-derived xenografts deprived of VEGF $_{165}$ b compared to control xenografts (Figure 3f) and conversely slightly increased in VEGF $_{165}$ b-overexpressing xenografts (Supplementary Figure 3c). Furthermore, a significant association between $\mathrm{VEGF}_{165} \mathrm{~b}$ and VEGFR1 levels (Figure $3 \mathrm{i}, \mathrm{p}=0.009$ ) was observed by immunohistochemistry in NSCLC patients, which was consistent with our in vitro results.

\section{VEGF $_{165}$ b promotes an invasive phenotype}

When performing all the above studies, we noticed that cells treated with rhVEGF $_{165} \mathrm{~b}$ or overexpressing $\operatorname{VEGF}_{165} \mathrm{~b}$ exhibited morphological changes that suggested phenotypic transformation (Figure 4a). Indeed, accumulation of EMT markers such as N-cadherin, fibronectin, vimentin, SNAIL or ZEB1 was observed upon treatment with rhVEGF $_{165} \mathrm{~b}$ (Figure 4b), in H358-VEGF ${ }_{165}$ b and $\mathrm{H} 1299-\mathrm{VEGF}_{165}$ b clones (Figure 4c), in H1299-VEGF ${ }_{165}$ b xenografts (Supplementary Figure 3d), as well as in H358-SRSF6 xenografts (Supplementary Figure 4e). Furthermore, we found that H1299-VEGF ${ }_{165}$ b clones close wounds faster than control cells (Figure 4d). Of note, H358 cells were not tested in wound healing assay as they never reach confluency when grown in Petri dishes. However, in transwell assays, H358VEGF $_{165} \mathrm{~b}$ clones transmigrated more efficiently than control cells (Figure 4e). H1299$\mathrm{VEGF}_{165} \mathrm{~b}$ clones also produced more pro-MMP9 and active MMP9 metalloproteinases (Figure 4f). Moreover, a reorganization of the actin cytoskeleton in stress fibers was observed in cells overexpressing VEGF $_{165}$ b (Figure $4 \mathrm{~g}$ ) or cultured with rhVEGF $_{165}$ b (Figure 4h). Cells exposed to rhVEGF ${ }_{165} \mathrm{~b}$ also had more focal adhesions (Figure 4i). As a whole, these results demonstrate that $\mathrm{VEGF}_{165} \mathrm{~b}$ promotes an invasive phenotype in $\mathrm{H} 358$ and $\mathrm{H} 1299$ lung adenocarcinoma cells. 


\section{VEGF $_{165} \mathrm{~b}$ stimulates an invasive $\beta 1$ integrin/VEGFR2 signaling pathway which triggers the formation of actin stress fibers and focal adhesions}

Next, we undertook a series of experiments to decipher the molecular mechanism(s) by which VEGF $_{165} \mathrm{~b}$ exhibits invasive properties. In endothelial cells, Chen and colleagues previously reported that matrix-bound $\mathrm{VEGF}_{165}$ is able to maintain the phosphorylation of VEGFR2 on its tyrosine 1214 residue leading to sustained activation of phospho-p38 MAPK. Such effects were dependent on the association of VEGFR2 with $\beta 1$ integrin (27). In our cellular models, we reproducibly observed that $\operatorname{rhVEGF}_{165} \mathrm{~b}$ triggers a sustained activation of $\mathrm{P}$ VEGFR2(Tyr1214) (Figures 3a-d). We also noticed the activation of p38 MAPK in H358VEGF $_{165} \mathrm{~b}$ clones together with expression of phospho-FAK and phospho-cofilin proteins, two targets of $\beta 1$ integrin signaling involved in actin polymerization (Figure 5a). Therefore, we postulated that the effects of $\mathrm{VEGF}_{165} \mathrm{~b}$ could be mediated through modulation of $\beta 1$ integrin expression and/or activation. To test this hypothesis, we first immunoprecipitated activated $\beta 1$ integrin in $\mathrm{H} 358-\mathrm{VEGF}_{165} \mathrm{~b}$ clones or in $\mathrm{H} 358$ cells that had been exposed to $\mathrm{rhVEF}_{165} \mathrm{~b}$ ligand. A slight but reproducible increased expression of activated $\beta 1$ integrin was detected in the immunoprecipitates of cells overexpressing VEGF $_{165} \mathrm{~b}$ (Figure 5b) or treated with $\operatorname{rhVEGF}_{165} \mathrm{~b}$ (Figure $5 \mathrm{c}$ ), whereas the total amount of $\beta 1$ integrin was not changed by any of the treatments. In agreement with a role of $\mathrm{VEGF}_{165} \mathrm{~b}$ on $\beta 1$ integrin activation, cell-surface activated $\beta 1$ integrin slightly increased in $\mathrm{H} 358$ or $\mathrm{H} 1299$ cells treated with $\mathrm{rhVEGF}_{165} \mathrm{~b}$ compared to untreated cells (Figure 5d). Altogether, these observations were consistent with the idea that $\mathrm{VEGF}_{165} \mathrm{~b}$ activates $\beta 1$ integrin to mediate its biological effects. To confirm the role of $\beta 1$ integrin, we used specific siRNA. We showed that $\beta 1$ integrin neutralization prevents the formation of actin stress fibers (Figure 5e) and focal adhesions (Figure 5f), cell migration (Figure 5g) and accumulation of phospho-VEGFR2(Tyr1214) and phospho- 
p38MAPK proteins (Figure 5h) in response to VEGF $_{165} \mathrm{~b}$. Moreover, using coimmunoprecipitation experiments, we demonstrated that $\mathrm{rhVGF}_{165} \mathrm{~b}$ treatment stimulates the formation of a complex between $\beta 1$ integrin and VEGFR2 (Figures $5 \mathrm{i}$ and 5j). Taken together, these results demonstrate that a cross-talk between VEGF $_{165} \mathrm{~b}, \mathrm{VEGFR}$ and $\beta 1$ integrin proteins promotes an invasive phenotype in lung adenocarcinoma cells.

\section{Bevacizumab increases $\mathrm{VEGF}_{165} \mathrm{~b}$ expression and promotes an invasive phenotype in lung cancer cells}

Although the humanized monoclonal antibody against VEGF-A, bevacizumab, is currently used in clinic for treatment of lung adenocarcinoma patients, the results are disappointing and the molecular mechanisms involved in tumor escape remain largely unknown. Interestingly, we showed that bevacizumab induces a dose-dependent intra-cellular accumulation of the VEGF $_{165}$ b protein in $\mathrm{H} 358$ cells (Figure 6a). In contrast, the level of pan-VEGF-A decreased in the same conditions (Figure 6a). Same results were obtained using semaxanib (SU5416), a VEGFR tyrosine kinase inhibitor (Figure 6b) and in H1299 cells (data not shown). Furthermore, treatment of human H358-xenografts in mice with bevacizumab up-regulated intra-tumoral $\mathrm{VEGF}_{165} \mathrm{~b}$ protein level as detected by immunohistochemistry (Figure 6c). Bevacizumab is currently used in combination with platinum salts for the treatment of NSCLC patients. We showed that cisplatin also increases the expression level of $\mathrm{VEGF}_{165} \mathrm{~b}$ in lung adenocarcinoma cell lines (Figure 6d). Interestingly, a stronger accumulation of VEGF $_{165} \mathrm{~b}$ occured upon co-treatment with cisplatin and bevacizumab (Figure 6d), and an elevated $V_{E G F}$ b:VEGF- $A_{\text {total }}$ ratio was observed in the sera of 4/10 lung adenocarcinoma patients following bevacizumab/cisplatin treatment (Supplementary Figure 7a, patients 6, 7, 9, 10). VEGF $_{165}$ b was found to represent $20 \%$ to $60 \%$ of all VEGF- $A_{\text {total }}$ in the sera of treated 
patients (data not shown). As a whole, these results are the first evidence that anti-angiogenic therapies used alone or in combination with cisplatin increase the expression of $V_{E G F} \mathrm{~b} b$. Of note, the specific neutralization of $\mathrm{VEGF}_{165} \mathrm{~b}$ in lung adenocarcinoma cell lines increased caspase-3 cleavage in response to cisplatin (Supplementary Figure 7b), suggesting that VEGF $_{165}$ b could also act as an inhibitor of apoptosis.

At the molecular level, we observed that bevacizumab induces the accumulation of phosphorylated VEGFR1/VEGFR2 and p38 MAPK in both H358 and H1299 cells (Figure 6e and Supplementary Figure 8a). This was prevented by the specific knock-down of $V_{E G F} b$. Increased P-VEGFR1(Tyr1213) immunostaining was also observed in bevacizumab-treated H358 xenografted mice, that was prevented by the knock-down of VEGF $_{165}$ b (Supplementary Figure $8 b$ ). These results clearly indicated that bevacizumab activates the VEGF $_{165} \mathrm{~b} /$ VEGFR autocrine loop in H358 and H1299 lung adenocarcinoma cell lines. We did not detect any significant effect of bevacizumab in vitro on ERK1/2 activation (Figure $6 \mathrm{e}$ and Supplementary Figure 8a) or cell proliferation (data not shown), nor on tumor growth in vivo (data not shown). However, the knock-down of $\mathrm{VEGF}_{165}$ b by siRNA significantly prevented the growth of bevacizumab-treated tumors, indicating that $\mathrm{VEGF}_{165} \mathrm{~b}$ is required for tumor growth both in untreated (Figure 2f) and bevacizumab-treated (data not shown) H358 xenografts. In addition, treatment of H1299 cells with bevacizumab for a long period of time (7 days) induced the expression of EMT markers such as N-cadherin, vimentin, fibronectin and $\alpha$-SMA proteins (Supplementary Figure $8 \mathrm{c}$ ). Although less pronounced, increased expression of vimentin was observed in H358 cells after 3 days of treatment (Figure 6e), as well as in bevacizumab-treated H358 xenografts (Supplementary Figure 8b). Furthermore, H358 cells exposed to bevacizumab also had more focal adhesions (Figure 6f) and more actin 
stress fibers (Figure $6 \mathrm{~g}$ ). All these events were prevented by the neutralisation of $\mathrm{VEGF}_{165} \mathrm{~b}$ using siRNA (Figure 6e, Figure $6 \mathrm{~g}$ and Supplementary Figures $8 \mathrm{a}$ and $8 \mathrm{~b}$ ). These data strongly suggested that $\mathrm{VEGF}_{165} \mathrm{~b}$ also triggers invasive functions upon bevacizumab treatment.

Finally, we investigated the contribution of the cross-talk between VEGF $_{165} \mathrm{~b}$, VEGFR2 and $\beta 1$ integrin to the response to bevacizumab. We found that bevacizumab treatment slightly but reproducibly induces $\beta 1$ integrin activation (Figure 7a) and more importantly stimulates the formation of a complex between activated $\beta 1$ integrin and VEGFR2 which was prevented by the knock-down of $\mathrm{VEGF}_{165} \mathrm{~b}$ (Figure $7 \mathrm{~b}$ ). In addition, the knock-down of $\beta 1$ integrin was found to prevent the formation of actin stress fibers (Supplementary Figure 9a) and focal adhesions (Supplementary Figure 9b) in H358 cells, and to inhibit cell migration in H1299 cells (Supplementary Figure 9c) upon treatment. Taken together, these results highly suggested that the cross-talk between $\mathrm{VEGF}_{165} \mathrm{~b}, \beta 1$ integrin and VEGFR2 proteins leads to an invasive phenotype in lung adenocarcinoma cell lines in response to bevacizumab treatment. 


\section{Discussion}

The $\mathrm{VEGF}_{165} \mathrm{~b}$ splice variant has been shown to inhibit angiogenic signaling of $\mathrm{VEGF}_{165}$ and its downregulation in primary melanoma was associated with subsequent metastasis $(14,19$, $20,28)$. It has not previously been shown to be upregulated in cancer, rather it is generally considered to be reduced as a proportion of total VEGF-A. In contrast, we find high levels of endogenous $\mathrm{VEGF}_{165} \mathrm{~b}$ protein in a significant proportion of lung adenocarcinoma. Furthermore, we observe an association between a high $\mathrm{VEGF}_{165} \mathrm{~b} / \mathrm{VEGF}_{165}$ ratio and lymph node metastases. Therefore, in parallel with $\mathrm{VEGF}_{165}$ triggering both invasive and antiinvasive functions (11), we highlight a complex role of $\mathrm{VEGF}_{165} \mathrm{~b}$ in tumors. In this new scheme, $\mathrm{VEGF}_{165} \mathrm{~b}$ cannot be viewed solely as a tumor suppressive anti-angiogenic factor, but has now also to be considered to be able to be an endogenous tumor promoting factor when cancer cells express VEGFRs. Importantly, we demonstrate that autocrine rather than paracrine functions of $\mathrm{VEGF}_{165} \mathrm{~b}$ are involved in this setting.

We provide the first evidence that $\mathrm{VEGF}_{165} \mathrm{~b}$ stimulates the proliferation and invasion of lung tumor cells. Importantly, we confirm the results in tumor xenografts and show that this is associated with a modulation of the KI67 proliferative index while CD31 or $\alpha$-SMA endothelial staining, two markers of tumor neo-angiogenesis, do not significantly vary. Paradoxically, we previously demonstrated that overexpression of $\operatorname{VEGF}_{165} \mathrm{~b}$ correlates with reduced angiogenesis in lung adenocarcinoma xenografts (29). In this former report, we only investigated the early paracrine effects of $V_{E G F} \mathrm{~b} b$ on neo-angiogenesis as mice were sacrificed 7 days after induction of $\mathrm{VEGF}_{165} \mathrm{~b}$. In the current study, mice were sacrificed 4145 days after tumor cells injection, thereby supporting the idea that autocrine tumor 
promoting functions of $\mathrm{VEGF}_{165} \mathrm{~b}$ may surpass its paracrine anti-angiogenic functions to promote lung tumor growth (Figure 8). Our results are in agreement with Catena and coworkers who noticed that stable overexpression of $\mathrm{VEGF}_{165} \mathrm{~b}$ promotes the development of lung ADC xenografts without affecting vascular density (17). In addition, our data are consistent with previous observations in various tumors such as renal cell carcinoma (30) or infiltrating breast carcinoma (17), where $\mathrm{VEGF}_{\mathrm{xx} x} \mathrm{~b}$ isoforms are not always down-regulated. On the other hand, $\mathrm{VEGF}_{165} \mathrm{~b}$ was also reported to slow-down the growth of colon cancer xenografts through inhibition of tumor neovascularization, without any effects on tumor proliferative rate (31-33). Therefore, whether $\mathrm{VEGF}_{165} \mathrm{~b}$ exerts anti- versus pro-tumoral functions may depend on the tumor type. One plausible but not exclusive explanation of these dual functions could come from the expression level of VEGFR receptors in tumors. In lung cancer that express VEGFR1/2 (6), we show that VEGF $_{165}$ b increases VEGFR1 and VEGFR2 mRNA levels, and triggers a sustained phosphorylation of both receptors which correlates with ERK1/2 and p38MAPK activation. In addition, we demonstrate that VEGF $_{165} \mathrm{~b}$ induces a $\beta 1$ integrin/VEGFR2/FAK/cofilin signaling pathway that promotes actin stress fiber formation, and show that $\beta 1$ integrin is required for the invasive functions of $V_{E G F}{ }_{165} \mathrm{~b}$. Taken together, these data provide a molecular rationale for the previous observation that upregulation of $\beta 1$ integrin correlates with advanced stages, lymph node metastases, increased relapse rate and decreased overall survival in lung adenocarcinoma patients (34).

The identification of predictive biomarkers of response to anti-angiogenic therapies is a crucial issue in the clinic. Eventhough these therapies were initially developed to target endothelial cells only, it is of prime importance to evaluate their impact on tumor cells themselves. In this study, we show that anti-angiogenic therapies combined (or not) with 
platinum salts regulate $V E G F-A$ alternative pre-mRNA splicing and specifically increase $\mathrm{VEGF}_{165} \mathrm{~b}$ levels in lung adenocarcinoma cell lines. In addition, we demonstrate that bevacizumab activates the $\mathrm{VEGF}_{165} \mathrm{~b} / \beta 1$ integrin/VEGFR signaling network leading to an invasive phenotype. Therefore, besides its ability to promote lung tumor growth, $\mathrm{VEGF}_{165} \mathrm{~b}$ appears to be also a determinant of the response to anti-angiogenic therapies. In this setting, our results support the very recent observation that integrin alpha 9 (ITGA9), known to form a heterodimeric receptor with activated $\beta 1$ integrin, belongs to a 10 gene-signature that predicts outcome in advanced non squamous NSCLC patients treated with a combination of bevacizumab and erlotinib $(35,36)$. They also fit well with the previous demonstration that $\beta 1$ integrin and its downstream effector kinase FAK are activated in bevacizumab-resistant glioblastoma patients and contribute to bevacizumab resistance $(37,38)$.

To conclude, we propose that a $\mathrm{VEGF}_{165} \mathrm{~b} / \mathrm{VEGFR} / \beta 1$ integrin autocrine loop contributes to the resistance of NSCLCs to anti-angiogenic therapies by promoting an invasive phenotype. This model is distinct but not contradictory to the results of Bates and colleagues who proposed that colon carcinoma patients exhibiting low levels of $\mathrm{VEGF}_{165} \mathrm{~b}$ are more sensitive to bevacizumab + FOLFOX treatment compared to FOLFOX alone (25). In that case, paracrine rather than autocrine functions of $\mathrm{VEGF}_{165} \mathrm{~b}$ are presumed to be at play. As a whole, these and our data highlight the need for addressing the respective status of VEGF-A splice variants and their paracrine/autocrine functions when investigating the global response to anti-angiogenic treatments. 


\section{Materials and Methods}

\section{Patients, Tissue samples and Serum}

Seventy six human Non Small Cell Lung Carcinoma (NSCLC) and 17 matched normal lung parenchymas were included in this study (Supplementary Table 1 and Supplementary Figures 1 and 2). Tissue banking and research conduct followed national ethical guidelines and were approved by the Ministry of Research (approval AC-2010-1129) and by the regional IRB (CPP 5 Sud Est). Histopathology diagnosis was made on formalin-fixed, paraffin-embedded samples using the current WHO classification $(39,40)$. For quantification of $\mathrm{VEGF}_{165} \mathrm{~b}$ in sera, blood samples from nine healthy subjects and ten patients with chemotherapy-naïve ADC enrolled in the Pharmacogenoscan study (NCT00222404; Grenoble University Hospital) were used (41). Informed consent was obtained from all subjects.

\section{Immunohistochemistry}

Antibodies recognizing specifically $\mathrm{VEGF}_{165}$ or $\mathrm{VEGF}_{165} \mathrm{~b}$ splice isoform were produced by immunizing rabbits with synthetic peptides specific of the C-terminal part of either VEGF $_{165}$ (LNERTCRCDKPRR) or VEGF $_{165}$ b (LNERTCRSLTRKD) protein (Covalab, Villeurbanne, France). The other antibodies used for immunohistochemistry are listed in Supplementary Table 2. Immunostaining was performed on $7 \mathrm{~mm}$ tissue sections as described previously (42) (43), and assessed by a pathologist (EB) who was blinded to the group allocation when scoring. Scoring (0-300) was established by multiplying the percentage of labelled cells (0 to $100 \%)$ by the staining intensity ( 0 , null; 1 , low; 2 , moderate; 3 , strong). Scores obtained for alveolar type II pneumocytes and bronchial cells in normal lung tissues taken at distance from the tumor were considered as normal scores for adenocarcinoma and squamous cell 
carcinoma, respectively. Tumors were sub-divided in three classes for $\mathrm{VEGF}_{165} \mathrm{~b}$ (class 0: low $\leq 50$; class 1: moderate 51-199; class 2: high $\geq 200$ ) and $\mathrm{VEGF}_{165}$ expression (class 0: low $\leq 50$; class 1: moderate 51-149; class 2: high $\geq 150$ ). For VEGFR1, tumors were sub-divided into two classes with low ( $<125$, class 0$)$ or high $(\geq 125$, class 1$)$ expression.

\section{Cells, Cell Culture and Reagents}

Human lung adenocarcinoma cell lines (H358, H1299) were recently authenticated by DNA STR profiling (ATCC cell line Authentification Service, LGC standards, Molsheim, France) and tested for mycoplasma contamination. Cells were cultured in RPMI-1640 medium + 2mM L-glutamine and 10\% (v/v) Fetal Calf Serum (FCS) as described previously (29). Bevacizumab (Avastin ${ }^{\circledR}$ ) was provided by Roche/Genetech (Indianapolis, USA). Recombinant $\mathrm{rhVEGF}_{165} \mathrm{~b}$ and $\mathrm{rhVEGF}_{165}$ proteins were purchased from R\&D Systems, SU5416 from Sigma-Aldrich and cisplatin and U0126 from Calbiochem. Stable VEGF ${ }_{165} \mathrm{~b}$ clones were obtained after transfection of H358 or H1299 cells using Fugene ${ }^{\circledR} 6$ reagent (Roche Diagnostic, France) with either pcDNA3 empty vector or pcDNA3-VEGF ${ }_{165} b$ encoding plasmids. Geneticin $(\mathrm{G} 418,800 \mu \mathrm{g} / \mathrm{ml})$ was added post-transfection for at least 4 weeks in order to select stable transfected clones. Two representative $\mathrm{VEGF}_{165} \mathrm{~b}$ overexpressing clones were chosen for H358 (clones 13 and 36) and H1299 (clones 2 and 5) cells.

\section{Apoptosis, wound healing, invasion, zymography and immunofluorescence studies}

Apoptosis was evaluated by scoring the percentage of apoptotic cells on 500 cells after Hoescht 33342 staining $(42,44)$. Wound-healing assays were performed using 4-well lab-tek 
chamber Permanox ${ }^{\circledR}$ slides, previously coated with fibronectin $(10 \mu \mathrm{g} / \mathrm{mL})$ and visualized using an inverted microscope equipped with a camera MicroMAX N/B (Princeton Instruments). Invasion assays in transwells using 50ng/mL $\beta$-FGF as a chemoattractant and analysis of the activity of MMP9 using gelatin zymography were performed as previously described $(45,46)$. Immunofluorescence studies for activated $\beta 1$ integrin (using 9EG7 antibody), phospho-paxillin(Tyr118) and F-actin were performed on cells coated onto $2 \mu \mathrm{g} / \mathrm{ml}$ fibronectin, fixed in 4\% PFA and permeabilized or not with PBS $1 \mathrm{X} /$ Triton $0.2 \%$. Cells were then mounted in a solution containing 4,6-diamino-2-phenylindole (DAPI) (Roti ${ }^{\circledR}$-Mount FluorCare DAPI, ROTH), visualized by fluorescent microscopy using Axioimager microscope (Carl Zeiss, Jena, Germany) with the AxioVision ${ }^{\circledR}$ software at a $60 \mathrm{x}$ magnification and processed with Image $\mathbf{J}$ software.

\section{Analysis of activated $\beta 1$ integrin by flow cytometry}

Cells re-suspended in PBS/BSA $1 \%$ (either with or without $\mathrm{Mn} 2+0.5 \mathrm{mM}$ ) to induce $\beta 1$ integrin activation were incubated with the primary antibody HUTS4 (MAB2079Z, SigmaAldrich) for $30 \mathrm{~min}$. After two washes with PBS, cells were incubated with Alexa ${ }^{488}$ anti-rat antibody, fixed with 4\% PFA and resuspended in PBS before flow cytometry analysis. The percentage of $\beta 1$ integrin activation was calculated using the formula: $\%$ activation $=($ Mean FL1-A [Ac] / Mean FL1-A [Ac+Mn2+]) x 100.

\section{ELISA assays}

VEGF $_{165} \mathrm{~b}$ was quantified on cellular extracts, cellular supernatants or serum using the R\&D system Duoset ELISA kit (cat\#DY3045) and pan-VEGF using either the Human VEGF 
Standard ELISA Development Kit from PeproTech (cat\# 900-K10) or the ELISA assay from R\&D System (DVE00).

\section{RNA interference, RNA extraction and quantitative RT-PCR}

$\beta 1$ integrin silencing was performed using SMARTpool siGENOME ITGB1 siRNA (Dharmacon) and Oligofectamine RNAi max (Invitrogen). The siRNA specifically targeting VEGF $_{165}$ b was: forward, 5'-GAACGUACUUGCAGAUCUCUC-3'; reverse, 5'GAGAGAUCUGCAAGUACGUUC-3'. The scrambled siRNA oligonucleotides used as a control for all RNA interference experiments were as follows: forward 5'UCGGCUCUUACGCAUUCAA-3' and reverse 5'-CAAGAAAGGCCAGUCCAAG-3' or ON-TARGET plus non targeting control pool (Dharmacon). Transfection was performed using Oligofectamine ${ }^{\mathrm{TM}}$ reagent (Invitrogen) and cells were analysed 72 hours posttransfection. The sequence for control siRNA used in in vivo experiments was designed as forward, 5'-CUUACGCUCACUACUGCGA-3'; and reverse, 5'UCGCAGUAGUGAGCGUAA-G-3'. Total RNA was extracted using Trizol® reagent (Invitrogen) and subjected to reverse transcription using iScript ${ }^{\mathrm{TM}}$ Reverse Transcription Supermix (BIO-RAD). Quantitative PCR was performed with GoTaq ${ }^{\circledR}$ qPCR Master Mix (Promega). VEGFR1/FLT1 (Hs.654360) and VEGFR2/KDR (Hs.479756) primer assays were purchased from TEBU-Bio (Le Perray-en-Yvelines, France). Relative gene expression was calculated, for each sample, as the ratio of specific target gene to GAPDH gene (reference gene), thus normalizing the expression of target gene for sample to sample differences in RNA input. 


\section{Immunoblotting and immunoprecipitation}

Immunoblotting and immunoprecipitation experiments were performed as previously described (47). The antibodies used are listed in the Supplementary Table 2. Sera for immunoprecipitation or detection of total (serum 227) or activated (TS2/16) $\beta 1$ integrin were provided by Dr Corinne Albiges-Rizo (Institute For Advanced Biosciences, La Tronche, France). For immunoprecipitation, $5 \mathrm{mM}$ sodium molybdate was added to the lysis buffer to enhance the cross-linking of the complexes. Irrelevant rabbit or mouse IgG was used as control for immunoprecipitation. Immunoblots were quantified using Image $\mathbf{J}$ software and the mean \pm standard deviation of at least three independent experiments was calculated. Owing to space constraints in some main figures, quantification of western blotting experiments is also provided in Supplementary Figure 10 and Supplementary Figure 11.

\section{In vivo studies}

All animal experiments were conducted in agreement with the "Principles of Laboratory Animal Care“ (NIH publication $n^{\circ} 86-23$, revised 1985) and were approved by the ComEth Grenoble ethic committee ( $\mathrm{n}^{\circ}$ of approval 165_IAB-U823-MK-11). In all experiments, H358, H358-Tet-On, H358-SRSF6, H1299-Luc or H1299-Luc-VEGF ${ }_{165}$ b cells were implanted subcutaneously $\left(10-20 \times 10^{6}\right.$ cells) into 5 to 6 weeks-old female Nmri nude mice (Janvier, Le Genest-Isle, France). Tumor volumes were measured once a week as previously described (48). H358 cells were allowed to form tumors for 3-4 weeks. When tumor volumes reached $30-40 \mathrm{~mm}^{3}$, mice were weighed, randomly divided into 4 homogeneous groups according to their weight (10 mice each) and were alternatively SC- or IP-injected four times a week, with either mismatch siRNA as a control or $V E G F_{165} b$ siRNA. Once a week, siRNAs were combined with either bevacizumab $(7.5 \mathrm{mg} / \mathrm{kg})$ or PBS as a control. Transfection of siRNA 
was performed using in vivo-jetPEI ${ }^{\mathrm{TM}}$-Gal (Polyplus-transfection). Tumor volumes were monitored throughout the experiment. In all experiments, the investigators $(\mathrm{AB}, \mathrm{SG}, \mathrm{MK}$, MG) were blinded to the group allocation during the experiment and when assessing the outcome. Mice were sacrificed after 6 weeks of treatment, tumors were removed, photographed, weighed, washed, fixed in Buffered Formaldehyde and processed for immunohistochemical analysis as previously detailed. Immunostainings were quantified using Image J software as previously described (49). In some experiments, tumoral samples were lysed in RIPA buffer supplemented just before use with proteases and phosphatases inhibitors and western blot experiments were performed on these samples. Statistical analysis of tumor volumes between groups was performed using a two-tailed non-parametric Mann-Whitney $t$ test (at least 9 animals per group).

\section{Statistical Analyses}

In all in vitro experiments on cell lines, at least three independent experiments were performed. MTS, apoptosis, proliferative and ELISA assays were always done in duplicate or triplicate for each experiment. Non-parametric, two-tailed Mann-Whitney or ANOVA tests were performed using Statview (Abacus Concepts) or Prism software. Descriptive analyses comparing continuous and two-level categorical variables were carried out using the MannWhitney test. P values $<0.05$ were considered significant.

\section{Conflict of Interest}

The authors declare no conflict of interest. 


\section{Acknowledgments}

Plasmid encoding VEGF $_{165} \mathrm{~b}$ was obtained from David Bates (University of Notthingham, UK). We thank Sophie Michallet, Floriane Albert, Celine Barrial and Virginie Rouyre for technical assistance. We also thank Laurence David-Boudet and Adrien Mombrun for IHC performance. Thanks to Philippe Lorimier for tumor bank gestion and data retrieving. This work was supported by the Comité Départemental Isère and Comité Départemental Savoie de la Ligue Nationale contre le Cancer, by the INCa/DHOS (Appel d'Offre Recherche Translationnelle 2010), by the Fondation de France (Projet Grande Ampleur 2011), by ROCHE fellowship (Bourse de Recherche Fondamentale), by the Fondation ARC pour la Recherche Contre le Cancer and by Fonds de dotation AGIR pour les Maladies Chroniques. Stephanie Gout and Tao Jia were supported by a post-doctoral fellowship from the Fondation ARC pour la Recherche Contre le Cancer. Asma Boudria was supported by the Ministere de l'Education et de la Recherche Algerien (program PROFAS) and by the Fondation pour La Recherche Médicale. Cherine Abou Faycal was supported by the Ligue Nationale Contre Le Cancer. The CAR team is supported by the Ligue Nationale Contre Le Cancer (Equipe labellisée Ligue 2014). 


\section{References}

1. Carmeliet P, Jain RK. Angiogenesis in cancer and other diseases. Nature. 2000;407(6801):249-57.

2. Ferrara N, Mass RD, Campa C, Kim R. Targeting VEGF-A to treat cancer and agerelated macular degeneration. Annu Rev Med. 2007;58:491-504.

3. Roskoski R, Jr. Vascular endothelial growth factor (VEGF) signaling in tumor progression. Crit Rev Oncol Hematol. 2007;62(3):179-213.

4. Ferrara N, Gerber HP, LeCouter J. The biology of VEGF and its receptors. Nat Med. 2003;9(6):669-76.

5. Goel HL, Mercurio AM. VEGF targets the tumour cell. Nat Rev Cancer.13(12):87182.

6. Lantuejoul S, Constantin B, Drabkin H, Brambilla C, Roche J, Brambilla E. Expression of VEGF, semaphorin SEMA3F, and their common receptors neuropilins NP1 and NP2 in preinvasive bronchial lesions, lung tumours, and cell lines. J Pathol. 2003;200(3):336-47.

7. Bachelder RE, Crago A, Chung J, Wendt MA, Shaw LM, Robinson G, et al. Vascular endothelial growth factor is an autocrine survival factor for neuropilin-expressing breast carcinoma cells. Cancer Res. 2001;61(15):5736-40.

8. Bachelder RE, Wendt MA, Mercurio AM. Vascular endothelial growth factor promotes breast carcinoma invasion in an autocrine manner by regulating the chemokine receptor CXCR4. Cancer Res. 2002;62(24):7203-6.

9. Goel HL, Chang C, Pursell B, Leav I, Lyle S, Xi HS, et al. VEGF/neuropilin-2 regulation of Bmi-1 and consequent repression of IGF-IR define a novel mechanism of aggressive prostate cancer. Cancer Discov.2(10):906-21. 
10. Lichtenberger BM, Tan PK, Niederleithner H, Ferrara N, Petzelbauer P, Sibilia M. Autocrine VEGF signaling synergizes with EGFR in tumor cells to promote epithelial cancer development. Cell.140(2):268-79.

11. Lu KV, Chang JP, Parachoniak CA, Pandika MM, Aghi MK, Meyronet D, et al. VEGF inhibits tumor cell invasion and mesenchymal transition through a MET/VEGFR2 complex. Cancer Cell.22(1):21-35.

12. Pajares MJ, Agorreta J, Larrayoz M, Vesin A, Ezponda T, Zudaire I, et al. Expression of tumor-derived vascular endothelial growth factor and its receptors is associated with outcome in early squamous cell carcinoma of the lung. J Clin Oncol.30(10):1129-36.

13. Robinson CJ, Stringer SE. The splice variants of vascular endothelial growth factor (VEGF) and their receptors. J Cell Sci. 2001;114(Pt 5):853-65.

14. Bates DO, Cui TG, Doughty JM, Winkler M, Sugiono M, Shields JD, et al. VEGF165b, an inhibitory splice variant of vascular endothelial growth factor, is downregulated in renal cell carcinoma. Cancer Res. 2002;62(14):4123-31.

15. Ladomery MR, Harper SJ, Bates DO. Alternative splicing in angiogenesis: the vascular endothelial growth factor paradigm. Cancer Lett. 2007;249(2):133-42.

16. Harris S, Craze M, Newton J, Fisher M, Shima DT, Tozer GM, et al. Do antiangiogenic VEGF (VEGFxxxb) isoforms exist? A cautionary tale. PLoS One.7(5):e35231.

17. Catena R, Larzabal L, Larrayoz M, Molina E, Hermida J, Agorreta J, et al. $\operatorname{VEGF}(1)(2)(1) b$ and VEGF(1)(6)(5)b are weakly angiogenic isoforms of VEGF-A. Mol Cancer.9:320.

18. Xin H, Zhong C, Nudleman E, Ferrara N. Evidence for Pro-angiogenic Functions of VEGF-Ax. Cell. 2016;167(1):275-84 e6.

19. Woolard J, Wang WY, Bevan HS, Qiu Y, Morbidelli L, Pritchard-Jones RO, et al. VEGF165b, an inhibitory vascular endothelial growth factor splice variant: mechanism of 
action, in vivo effect on angiogenesis and endogenous protein expression. Cancer Res. 2004;64(21):7822-35.

20. Pritchard-Jones RO, Dunn DB, Qiu Y, Varey AH, Orlando A, Rigby H, et al. Expression of $\operatorname{VEGF}(\mathrm{xxx}) \mathrm{b}$, the inhibitory isoforms of $\mathrm{VEGF}$, in malignant melanoma. $\mathrm{Br} \mathrm{J}$ Cancer. 2007;97(2):223-30.

21. Kawamura H, Li X, Harper SJ, Bates DO, Claesson-Welsh L. Vascular endothelial growth factor (VEGF)-A165b is a weak in vitro agonist for VEGF receptor-2 due to lack of coreceptor binding and deficient regulation of kinase activity. Cancer Res. 2008;68(12):468392.

22. Cebe Suarez S, Pieren M, Cariolato L, Arn S, Hoffmann U, Bogucki A, et al. A VEGF-A splice variant defective for heparan sulfate and neuropilin-1 binding shows attenuated signaling through VEGFR-2. Cell Mol Life Sci. 2006;63(17):2067-77.

23. Lambrechts D, Lenz HJ, de Haas S, Carmeliet P, Scherer SJ. Markers of response for the antiangiogenic agent bevacizumab. J Clin Oncol.31(9):1219-30.

24. Rugo HS. Inhibiting angiogenesis in breast cancer: the beginning of the end or the end of the beginning? J Clin Oncol.30(9):898-901.

25. Bates DO, Catalano PJ, Symonds KE, Varey AH, Ramani P, O'Dwyer PJ, et al. Association between VEGF splice isoforms and progression-free survival in metastatic colorectal cancer patients treated with bevacizumab. Clin Cancer Res.18(22):6384-91.

26. Nowak DG, Woolard J, Amin EM, Konopatskaya O, Saleem MA, Churchill AJ, et al. Expression of pro- and anti-angiogenic isoforms of VEGF is differentially regulated by splicing and growth factors. J Cell Sci. 2008;121(Pt 20):3487-95.

27. Chen TT, Luque A, Lee S, Anderson SM, Segura T, Iruela-Arispe ML. Anchorage of VEGF to the extracellular matrix conveys differential signaling responses to endothelial cells. J Cell Biol.188(4):595-609. 
28. Diaz R, Pena C, Silva J, Lorenzo Y, Garcia V, Garcia JM, et al. p73 Isoforms affect VEGF, VEGF165b and PEDF expression in human colorectal tumors: VEGF165b downregulation as a marker of poor prognosis. Int J Cancer. 2008;123(5):1060-7.

29. Merdzhanova G, Gout S, Keramidas M, Edmond V, Coll JL, Brambilla C, et al. The transcription factor E2F1 and the SR protein SC35 control the ratio of pro-angiogenic versus antiangiogenic isoforms of vascular endothelial growth factor-A to inhibit neovascularization in vivo. Oncogene.29(39):5392-403.

30. Grepin R, Guyot M, Jacquin M, Durivault J, Chamorey E, Sudaka A, et al. Acceleration of clear cell renal cell carcinoma growth in mice following bevacizumab/Avastin treatment: the role of CXCL cytokines. Oncogene.31(13):1683-94.

31. Varey AH, Rennel ES, Qiu Y, Bevan HS, Perrin RM, Raffy S, et al. VEGF 165 b, an antiangiogenic VEGF-A isoform, binds and inhibits bevacizumab treatment in experimental colorectal carcinoma: balance of pro- and antiangiogenic VEGF-A isoforms has implications for therapy. Br J Cancer. 2008;98(8):1366-79.

32. Rennel ES, Hamdollah-Zadeh MA, Wheatley ER, Magnussen A, Schuler Y, Kelly SP, et al. Recombinant human VEGF165b protein is an effective anti-cancer agent in mice. Eur $\mathbf{J}$ Cancer. 2008;44(13):1883-94.

33. Rennel E, Waine E, Guan H, Schuler Y, Leenders W, Woolard J, et al. The endogenous anti-angiogenic VEGF isoform, VEGF165b inhibits human tumour growth in mice. Br J Cancer. 2008;98(7):1250-7.

34. Zhang PF, Zeng GQ, Yi LZ, Liu JP, Wan XX, Qu JQ, et al. Identification of integrin beta1 as a prognostic biomarker for human lung adenocarcinoma using 2D-LC-MS/MS combined with iTRAQ technology. Oncol Rep.30(1):341-9.

35. Cascone T, Heymach JV. Can the Lung Cancer Pie Be Divided into Angiogenic Slices? Clin Cancer Res. 
36. Franzini A, Baty F, Macovei, II, Durr O, Droege C, Betticher D, et al. Gene expression signatures predictive of bevacizumab/erlotinib therapeutic benefit in advanced non-squamous non-small cell lung cancer patients (SAKK 19/05 trial). Clin Cancer Res.

37. Carbonell WS, DeLay M, Jahangiri A, Park CC, Aghi MK. beta1 integrin targeting potentiates antiangiogenic therapy and inhibits the growth of bevacizumab-resistant glioblastoma. Cancer Res.73(10):3145-54.

38. Huveldt D, Lewis-Tuffin LJ, Carlson BL, Schroeder MA, Rodriguez F, Giannini C, et al. Targeting Src family kinases inhibits bevacizumab-induced glioma cell invasion. PLoS One.8(2):e56505.

39. Beasley MB, Brambilla E, Travis WD. The 2004 World Health Organization classification of lung tumors. Semin Roentgenol. 2005;40(2):90-7.

40. Travis WD, Brambilla E, Noguchi M, Nicholson AG, Geisinger KR, Yatabe Y, et al. International association for the study of lung cancer/american thoracic society/european respiratory society international multidisciplinary classification of lung adenocarcinoma. $\mathbf{J}$ Thorac Oncol.6(2):244-85.

41. Toffart AC, Timsit JF, Couraud S, Merle P, Moro-Sibilot D, Perol M, et al. Immunohistochemistry evaluation of biomarker expression in non-small cell lung cancer (Pharmacogenoscan study). Lung Cancer.83(2):182-8.

42. Salon C, Merdzhanova G, Brambilla C, Brambilla E, Gazzeri S, Eymin B. E2F-1, Skp2 and cyclin E oncoproteins are upregulated and directly correlated in high-grade neuroendocrine lung tumors. Oncogene. 2007;26(48):6927-36.

43. Gout S, Brambilla E, Boudria A, Drissi R, Lantuejoul S, Gazzeri S, et al. Abnormal expression of the pre-mRNA splicing regulators SRSF1, SRSF2, SRPK1 and SRPK2 in non small cell lung carcinoma. PLoS One.7(10):e46539. 
44. Merdzhanova G, Edmond V, De Seranno S, Van den Broeck A, Corcos L, Brambilla C, et al. E2F1 controls alternative splicing pattern of genes involved in apoptosis through upregulation of the splicing factor SC35. Cell Death Differ. 2008;15(12):1815-23.

45. Hall DM, Brooks SA. In vitro invasion assay using matrigel: a reconstituted basement membrane preparation. Methods Mol Biol. 2014;1070:1-11.

46. Toth M, Sohail A, Fridman R. Assessment of gelatinases (MMP-2 and MMP-9) by gelatin zymography. Methods Mol Biol. 2012;878:121-35.

47. Salon C, Eymin B, Micheau O, Chaperot L, Plumas J, Brambilla C, et al. E2F1 induces apoptosis and sensitizes human lung adenocarcinoma cells to death-receptormediated apoptosis through specific downregulation of c-FLIP(short). Cell Death Differ. 2006;13(2):260-72.

48. Eymin B, Leduc C, Coll JL, Brambilla E, Gazzeri S. p14ARF induces G2 arrest and apoptosis independently of p53 leading to regression of tumours established in nude mice. Oncogene. 2003;22(12):1822-35.

49. Larrayoz M, Pio R, Pajares MJ, Zudaire I, Ajona D, Casanovas O, et al. Contrasting responses of non-small cell lung cancer to antiangiogenic therapies depend on histological subtype. EMBO Mol Med. 2014;6(4):539-50. 


\section{Figure legends}

Figure 1. VEGF Vis $\mathrm{b}$ is highly expressed in a significant proportion of Non Small Cell Lung Carcinomas (NSCLCs) and a high VEGF $_{165} \mathrm{~b}_{\text {VEGF }}$ (165 ratio is associated with lymph node metastases. (a, b) Upper panels: representative $\mathrm{VEGF}_{165} \mathrm{~b}$ or $\mathrm{VEGF}_{165}$ immunostaining from paraffin-embedded sections of acinous lung adenocarcinoma (a) or well-differentiated squamous cell lung carcinoma (b). Negative controls (no Ab, IgG) for immunostainings are illustrated in left panels for each histological sub-type. Lower panels: distribution of $\mathrm{VEGF}_{165}$ and $\mathrm{VEGF}_{165} \mathrm{~b}$ scores for each tumor case. Statistical analyses were performed using a Student paired t test. Scale bar $=50 \mu \mathrm{m}$. (c) Mean levels \pm standard deviation of $\mathrm{VEGF}_{165} \mathrm{~b}$ immunohistochemical scores according to the histological sub-type. (d) Quantification (Elisa) of $\mathrm{VEGF}_{165} \mathrm{~b}$ in blood samples of healthy controls and chemotherapy-naïve adenocarcinoma patients (ADC). Median levels are indicated. Of note, circulating $\mathrm{VEGF}_{165} \mathrm{~b}$ levels never correlated with platelet count, nor the time at which these sera were collected (from 4 to 12 weeks after the start of treatment) (data not shown). (e) Distribution of the $\mathrm{VEGF}_{165} \mathrm{~b}: \mathrm{VEGF}_{165}$ ratio (IHC) according to the nodal status in NSCLC. (c, d, e) Statistical analyses were performed using a non-parametric Mann-Whitney test.

Figure 2. VEGF ${ }_{165}$ b promotes cellular proliferation and lung tumor growth. (a) Cell proliferation was assessed by counting trypan blue negative cells in two stable $\mathrm{VEGF}_{165} \mathrm{~b}$ clones derived from either H358 (named 13 and 36) or H1299 (named 2 and 5) cells respectively, or (b) in H358 and H1299 native cells cultured with supernatants from either control H358 or H1299 cells or $\mathrm{VEGF}_{165}$ b-clones as indicated, or (c) in H358 and H1299 cells treated with $\mathrm{rhVGF}_{165} \mathrm{~b}(0.1 \mathrm{ng} / \mathrm{ml})$ for 72 hours or $(\mathbf{d})$ in $\mathrm{H} 358$ and H1299 cells transfected with either mismatch or $V E G F_{165} b$ siRNA for 72 hours. The means \pm SD of three independent 
experiments are illustrated (a, one-way ANOVA; c,d non parametric Mann-Whitney test). * $\mathrm{p}<0.05$; $* * \mathrm{p}<0.01$. (d) Lower panel: Western blot analysis using anti-VEGF ${ }_{165} \mathrm{~b}$ or antiVEGF $_{165}$ antibody was perform to assess the specific knock-down of VEGF $_{165}$ b. Tubulin was used as a loading control. (e, f, g) H358 cells were sub-cutaneously injected into nude mice to form tumors. Animals were then sub-divided in two groups ( $\mathrm{n}=9$ for each group), receiving mismatch or $V E G F_{165} b$ siRNA. (e) Upper panels: representative $V_{E G F}{ }_{165} \mathrm{~b}$ and $\mathrm{VEGF}_{165}$ immunostainings in H358 xenografts having received either control (mismatch) or $\mathrm{VEGF}_{165} \mathrm{~b}$ $\left(\right.$ siVEGF $\left.F_{165} b\right)$ siRNA. Scale bar $=50 \mu \mathrm{m}$. Lower histograms: quantification of immunostainings as described in the material and methods section. Statistical analyses were performed using non-parametric Mann-Whitney test. ${ }^{*} \mathrm{p}<0.05$; NS: not significant. (f) Upper panels: representative tumors. Lower panel: mean tumor volume \pm SD in each condition. Statistical analyses were performed using non-parametric Mann-Whitney test. $* \mathrm{p}<0.05$. (g) Left panels represent immunostainings of KI67. Scale bar $=50 \mu \mathrm{m}$. Right panel: histogram of the percentage of KI67-stained tumor cells for each condition. Five fields containing at least 100 cells were scored for each tumor xenograft. ** $\mathrm{p}<0.01$ using non parametric MannWhitney test.

Figure 3. VEGF ${ }_{165} \mathrm{~b}$ activates a VEGFR autocrine loop to promote tumor cells proliferation. (a, c) Immunoblots for indicated proteins in H358 or H1299 cells treated with $\operatorname{rhVEGF}_{165} \mathrm{~b}(0.1 \mathrm{ng} / \mathrm{ml})$ for 72 hours (a) or in $\mathrm{H} 358$ or $\mathrm{H} 1299 \mathrm{VEGF}_{165}$ b-overexpressing clones (c). Actin was used as a loading control. (b, d) Quantification of immunoblots in (a) and (c) respectively, using Image $\mathbf{J}$ software. An arbitrary value of 1 was given to untreated or control (Co) cells (black histogram). Values are mean \pm SD of 3 independent experiments. Non-parametric Mann-Whitney statistical test. $\left(* * \mathrm{p}<0.01,{ }^{*} \mathrm{p}<0.05, \mathrm{NS}\right.$ : not significant). (e) $\mathrm{H} 358$ control or $\mathrm{H} 358 \mathrm{VEGF}_{165}$ b-clones were treated or not for 48 hours with $10 \mu \mathrm{M}$ U0126 as 
indicated. Cell number was estimated following trypan blue staining. Values are mean \pm SD of 3 independent experiments. (Non-parametric Mann-Whitney test, *** $\mathrm{p}<0.001)$. (f) Representative immunostaining of P-VEGFR1(Tyr1213) or VEGFR1 proteins in H358 xenografts having received either mismatch or $V E G F_{165} b$ siRNA as indicated. Scale bar $=50$ $\mu \mathrm{m}$. (g) H358 or H1299 cells were treated ( rhVEGF $_{165} \mathrm{~b}$, hatched bars) or not (NT, white bars), for 72 hours with $\mathrm{rhVEGF}_{165} \mathrm{~b}(0.1 \mathrm{ng} / \mathrm{ml})$ as indicated. VEGFRl or VEGFR2 mRNA levels were quantified by RT-QPCR in each condition. GAPDH was used as an internal control. (h) VEGFR1 (white bars) or VEGFR2 (hatched bars) mRNA levels were quantified by RT-QPCR in control cells (pcDNA3.1 transfected) or H358 or H1299 clones overexpressing $\mathrm{VEGF}_{165}$ b. GAPDH was used as an internal control. (i) Mean levels \pm standard deviation of VEGF $_{165} \mathrm{~b}$ immunohistochemical scores according to the expression of VEGFR1 (high and low) in NSCLC patients. (g, h, i) Statistical analyses were performed using nonparametric Mann-Whitney test $(* * \mathrm{p}<0.01 ; * * * \mathrm{p}<0.001)$.

Figure 4. VEGF ${ }_{165}$ b promotes invasion. (a) Microscopic visualization of morphological differences between $\mathrm{H} 358 / \mathrm{H} 1299$ control and VEGF $_{165}$ b-overexpressing cells. (b, c) Immunoblots for Epithelial to Mesenchymal Transition (EMT) markers in H358 cells treated or not with $0.1 \mathrm{ng} / \mathrm{ml} \operatorname{rhVEGF}_{165}$ b for 72 hours (b) or in control (Co), H358 and H1299VEGF $_{165}$ b clones $(\mathbf{c})$. Actin or tubulin was used as a loading control. (d) Wound healing assay in control and $\mathrm{H} 1299-\mathrm{VEGF}_{165} \mathrm{~b}$ clones (5 and 2). Scratch recovering was estimated after 13 hours. Right histogram represents the scratch coverage percentage. $n=3$ independent experiments. Values are mean $\pm \mathrm{SD}$ (non parametric Mann-Whitney test). ** $\mathrm{p}<0.01$. (e) Boyden chamber assay in control and $\mathrm{H} 358-\mathrm{VEGF}_{165} \mathrm{~b}$ clones (13 and 36) using serum gradient and $\beta$-FGF as attractants. Trans-migrating cells were stained with Hoechst as illustrated in upper panels. $\mathrm{n}=3$ independent experiments. Values are mean \pm SD (non 
parametric Mann-Whitney test). $* \mathrm{p}<0.05 * * \mathrm{p}<0.01$. (f) Representative immunoblots of MMP-9 gelatin zymography in $\mathrm{H} 1299-\mathrm{VEGF}_{165}$ b clones. The supernatant from HT1080 cell line was used as a control for MMPs activation. (g) F-actin staining using phalloidin-TRITC in $\mathrm{H} 1299$ control or $-\mathrm{VEGF}_{165}$ b clones. (h) Representative F-actin staining of H1299 cells treated, or not $(\mathrm{Co})$, with $\mathrm{rhVEGF}_{165} \mathrm{~b}(1 \mathrm{ng} / \mathrm{ml})$ for $60 \mathrm{~min}$ (upper panel). Percentages of cells with actin stress fibers are presented for each condition (lower panel). $n=4$ independent experiments. 500 cells were counted per experiment. Values are mean \pm SD (Mann-Whitney test). (i) H1299 were plated onto fibronectin glass coverslips for 24 hours and treated or not for 1 hour with $\operatorname{rhVEGF}_{165} \mathrm{~b}(1 \mathrm{ng} / \mathrm{ml})$. Co-immunofluorescence analyses of activated $\beta 1$ integrin (clone 9EG7, green) and phospho-paxillin(Tyr118) (red) were performed. DAPI was used to counterstain the nucleus. Histograms representing quantification of cells exhibiting focal adhesion was performed on at least 300 cells (Mann-Whitney test) $* \mathrm{p}<0.05$. Scale bar $=$ $20 \mu \mathrm{m}$.

\section{Figure 5. VEGF ${ }_{165} \mathrm{~b}$ activates a $\beta 1$ integrin signaling pathway to trigger actin} cytoskeleton reorganization. (a) Immunoblots of the indicated proteins in control and $\mathrm{H} 358$ VEGF $_{165} \mathrm{~b}$ clones. Tubulin was used as a loading control. Same results were obtained in H1299-VEGF ${ }_{165}$ b clones (data not shown). (b, c) Immunoprecipitation (IP) of activated $\beta 1$ integrin in cellular extracts from (b) $\mathrm{H} 358$ control or $-\mathrm{VEGF}_{165}$ b clones or (c) $\mathrm{H} 358$ treated with $\mathrm{rhVEGF}_{165}$ or $\mathrm{rhVEGF}_{165} \mathrm{~b}(0.1 \mathrm{ng} / \mathrm{ml})$ for $60 \mathrm{~min}$. IgG was used as an irrelevant antibody. Total amount of $\beta 1$ integrin in protein extracts was assessed by western blotting (lower panels). Numbers represent the results of densitometric quantification of the signal using image $J$ software. The ratio activated $\beta 1$ integrin:total $\beta 1$ integrin in untreated cells was arbitrarily assigned the value 1 . (d) $\beta 1$ integrin activation measured by flow cytometry in 
H358 or H1299 cells treated or not (NT) for 1 hour with $\mathrm{rhVEF}_{165} \mathrm{~b}(10 \mathrm{ng} / \mathrm{ml})$. The mean \pm SDs of four independent experiments are presented. (non parametric Mann-Whitney test). (e) F-actin staining using phalloidin-TRITC in $\mathrm{H}_{12} 99-\mathrm{VEFG}_{165} \mathrm{~b}$ clones transfected for 72 hours with mismatch (siMis) or $\beta 1$ integrin (si $\beta 1$ ) siRNA. Scale bar $=20 \mu \mathrm{m}$. Same results were obtained in H1299 cells transfected for 72 hours with mismatch (siMis) or $\beta 1$ integrin (si $\beta 1$ ) siRNA and treated or not with $\operatorname{rhVEGF}_{165} \mathrm{~b}(0.1 \mathrm{ng} / \mathrm{ml})$ for $30 \mathrm{~min}$ (data not shown). (f) H1299 cells were transfected with mismatch or $\beta 1$ integrin siRNA for 48 hours, plated onto fibronectin coated glass coverslips for 24 hours and treated, or not, for 1 hour with $\operatorname{rhVEGF}_{165} \mathrm{~b}(1 \mathrm{ng} / \mathrm{ml})$. Co-immunofluorescence staining was performed to detect $\beta 1$ integrin (green) and phospho-paxillin(Tyr118) (red). Dapi was used to counterstain the nucleus. Of note, the green fluorescence strongly decreased in $\beta 1$ integrin knocked-down cells consistent with the efficiency of $\beta 1$ integrin knock-down. Scale bar $=20 \mu \mathrm{m}$. (g) A wound healing assay was performed in $\mathrm{H} 1299-\mathrm{VEFG}_{165}$ b clones transfected with control (siMis) or siRNA against $\beta 1$ integrin (si $\beta 1$ ). Scratch recovery was estimated after 13 hours. The right panel represents the scratch coverage percentage. $n=3$ independent experiments. Values are mean $\pm \mathrm{SD}$ (non parametric Mann-Whitney test) $* \mathrm{p}<0.05$. (h) H1299 were transfected for 72 hours with mismatch (siMis) or $\beta 1$ integrin (si $\beta 1$ ) siRNA in the presence or absence of $\operatorname{rhVEGF}_{165} \mathrm{~b}$ $(0.1 \mathrm{ng} / \mathrm{ml})$ as indicated. Western-blot analysis of the indicated proteins was performed. Tubulin was used as a loading control. (i, j) Immunoprecipitation of (i) $\beta 1$ integrin or (j) VEGFR2 was performed in $\mathrm{H} 358$ cells treated or not with increasing amounts $(0.1,1 \mathrm{ng} / \mathrm{ml})$ of rhVEGF $_{165}$ b for 1 hour. IgG was used as an irrelevant antibody. Numbers represent the results of densitometric quantification of the signal using image $\mathrm{J}$ software. For VEGFR2 and $\beta 1$ integrin interaction, the VEGFR2: $\beta 1$ ratio was calculated in each condition. The value 1 was arbitrarily assessed in untreated conditions. 
Figure 6. Anti-angiogenic therapies such as bevacizumab increase VEGF ${ }_{165}$ b protein level and promote the invasive phenotype. $(\mathbf{a}, \mathbf{b})$ Intra-cellular dosage (Elisa) of $\mathrm{VEGF}_{165} \mathrm{~b}$ and pan-VEGF-A in H358 cells, treated or not (NT), with (a) bevacizumab for 72 hours or (b) semaxanib (SU5416) for 48 hours. $\mathrm{n}=3$ independent experiments. Values are mean \pm SD (non-parametric Mann-Whitney test; * $\mathrm{p}<0.05, * * \mathrm{p}<0.01$ ). Same results were obtained in H1299 cells (data not shown). (c) Representative immunostaining of VEGF $_{165}$ b in H358 subcutaneous xenografts having received or not bevacizumab $(7.5 \mathrm{mg} / \mathrm{kg})$ once a week. Scale bar $=50 \mu \mathrm{m} .(\mathbf{d}) \mathrm{H} 358$ or H1299 cells were treated, or not (NT), for 72 hours with either $5 \mu \mathrm{M}$ cisplatin or a combination of $5 \mu \mathrm{M}$ cisplatin and $1 \mu \mathrm{g} / \mathrm{ml}$ bevacizumab. ELISA assays were performed in intracellular extracts. $\mathrm{n}=3$ independent experiments. Values are mean $\pm \mathrm{SD}$ (non-parametric Mann-Whitney; * $\mathrm{p}<0.05$; ** $\mathrm{p}<0.01$ ). (e) Immunoblots for indicated proteins in $\mathrm{H} 358$ cells transfected with mismatch or $V E G F_{165} b$ siRNA for 72 hours and incubated or not with increasing doses of bevacizumab as indicated. Tubulin was used as a loading control. (f) H1299 were plated onto fibronectin glass coverslips for 24 hours and treated or not for 72 hours with bevacizumab. Co-immunofluorescence analyses of $\beta 1$ integrin (green) and phospho-paxillin(Tyr118) (red) were performed. DAPI was used to counterstain the nucleus. Scale bar $=10 \mu \mathrm{m}$. Histograms represent quantification of cells exhibiting focal adhesion on at least 300 cells (non-parametric Mann-Whitney; $* * p<0.01)$. (g) F-actin staining using phalloidin-TRITC in H1299 cells transfected with mismatch or $V E G F_{165} b$ siRNA and treated or not with BVZ $(10 \mu \mathrm{g} / \mathrm{ml})$ for 72 hours. Scale bar $=10 \mu \mathrm{m}$.

Figure 7. Bevacizumab promotes the formation of $\beta 1$ integrin/VEGFR2 complex by a mechanism involving VEGF $_{165}$ b. (a) Left panels: Immunoprecipitation (IP) of activated $\beta 1$ integrin in cellular extracts from H358 cells treated or not with increasing concentrations of 
bevacizumab for 72 hours as indicated. IgG was used as an irrelevant antibody. Total amount of $\beta 1$ integrin in protein extracts was assessed by western blotting (lower panels). Numbers represent the results of densitometric quantification of the signal using image $\mathrm{J}$ software. Activated $\beta 1$ integrin:total $\beta 1$ integrin ratio in untreated cells was arbitrarily assigned to 1 . Right panel: Densitometric quantification (mean $\pm \mathrm{SD}$ ) of the activated $\beta 1$ integrin:total $\beta 1$ integrin ratio in three independent experiments. The value 1 was arbitrarily assigned to the ratios obtained in untreated cells (non-parametric Mann-Whitney test; ${ }^{*}$ p<0.05). (b) Left panels: Immunoprecipitation of activated $\beta 1$ integrin in $\mathrm{H} 358$ cells transfected with mismatch or $V E G F_{165} b$ siRNA and treated or not (-) with bevacizumab $(10 \mu \mathrm{g} / \mathrm{ml})$ for 72 hours. Lower panel: efficiency of $\mathrm{VEGF}_{165} \mathrm{~b}$ knock-down. IgG was used as an irrelevant antibody. Numbers represent the results of densitometric quantification using image $\mathbf{J}$ software of the VEGFR2: $\beta 1$ integrin ratio in each condition. The value 1 was arbitrarily assigned to untreated conditions. Right panel: Densitometric quantification (mean \pm SD) of the VEGFR2: $\beta 1$ integrin ratio in three independent experiments. The value 1 was arbitrarily assigned to the ratio obtained in untreated cells (non-parametric Mann-Whitney test; ${ }^{*} \mathrm{p}<0.05,{ }^{* *} \mathrm{p}<0.01$ ).

Figure 8. A model for the dual functions of $\mathrm{VEGF}_{165} \mathbf{b}$ in NSCLC. In lung tumors, $\mathrm{VEGF}_{165} \mathrm{~b}$ can exert both paracrine anti-angiogenic functions on endothelial cells (our former study, (29)), as well as pro-tumoral functions on tumor cells themselves through activation of a $\beta 1$ integrin/VEGFR autocrine loop (this study). We propose that in later stages of tumor development, the pro-tumoral proliferative functions of $\mathrm{VEGF}_{165} \mathrm{~b}$ may bypass the antitumoral angiogenic ones to promote tumor progression. $\mathrm{VEGF}_{165} \mathrm{~b}$-expressing tumor cells also acquire more aggressive and invasive features as evidenced by the appearance of EMT markers that could contribute to the metastatic spreading of tumor cells. Anti-angiogenic 
therapies impact on $V E G F-A$ pre-mRNA splicing and favor the expression of $V_{E G F}$ b in tumor cells that could promote their escape from treatment. Based on preliminary results indicating that $\mathrm{VEGF}_{165} \mathrm{~b}$-overexpressing cells are also more resistant to hypoxia, we propose that hypoxia induced by anti-angiogenic therapies may also contribute to the emergence of VEGF $_{165} \mathrm{~b}$-expressing tumor cells. As a whole, our data suggest that modulating VEGF-A premRNA splicing together with $\beta 1$ integrin signaling might offer alternative therapeutic strategies to overcome resistance to anti-angiogenic therapies in lung adenocarcinoma. 